\title{
Original Article \\ Perceptions of Academic Achievers and Under Achievers Regarding Educational Environment of Medical Colleges in Bangladesh
}

\author{
N Nahar ${ }^{1}$, Md. HK Talukder ${ }^{2}$, Md. T H Khan ${ }^{3}$
}

\begin{abstract}
Educational environment in any medical institute is found to be important in determining student's academic success. This cross sectional descriptive study was undertaken with the aim to explore the perception of academic achievers and under achievers on educational environment using the Dundee Ready Education Environment Measure (DREEM) inventory. The inventory was administered to 1610 medical students of clinical phase (3rd, 4th and 5th year) of $M B B S$ course adopting purposive sampling. Study revealed that the total mean DREEM score of academic achievers was high (110/200) compared to under achievers (106/200). Academic achievers also scored high in all domain than academic under achievers but significantly high in two domains i.e. students' academic self perception and perception of
\end{abstract}

\section{Introduction}

Curriculum is considered to be the most holistic, inclusive and comprehensive entity and notion in education. ${ }^{1}$ Curriculums most significant manifestation and conceptualization is the environment, educational and organizational, which embraces everything that is happening in the medical school. Educational environment in any medical institute is found to be important for effective management of learning. ${ }^{2}$ A good learning environment is vital for the delivery of quality training. ${ }^{3}$ It is well known that any curriculum generates and establishes environments and changes in curriculum are thus essentially changes in environment. ${ }^{2}$

1 Dr. Nurun Nahar, Associate Professor, Department of Pharmacology, East West Medical College, Dhaka

2 Dr. Md. Humayun Kabir Talukder, Associate Professor (Teaching Methodology) \& Course Co-ordinator, MMEd, Centre for Medical Education, Mohakhali, Dhaka

3 Dr. Md. Tafazzal Hossain Khan, OSD , DGHS, Dhaka Address of correspondence: nurunnahar004@gmail.com atmosphere. Gender wise comparison shows that female students of academic achievers (112/200) and under achievers $(108 / 200)$ perceive the environment more positive than male students of academic achievers (108/200) and underachievers (104/200). Though both academic achievers and under achievers perceive the environment positive but interventions are to be needed to correct the problems of areas specially in the subscales of academic self perception and perception of atmosphere. Finally the results of this study may provide a useful basis for strategic planning and resource utilization for further improvement of educational environment.

Key words: perception, educational environment, academic achiever, academic under-achiever, medical college

The quality of educational environment has been identified to be crucial for effective learning and there is a proven connection between the environment and the valuable outcome of students' achievement, satisfaction and success. ${ }^{1,2}$ Educational environment influences how, why and what student's learn. ${ }^{4}$ Perceptions of poor performers are significantly different from those of better performers in the same institution..$^{5,6}$ Successful management in education is only possible with systemic feedback and assessment of educational environment. ${ }^{7}$ As students' perceptions of their educational environment strongly affects students achievement and success so it is important to assess the educational environment of an institute on a regular basis in order to nurture areas of excellence and to identify areas needing attention. ${ }^{8}$

The undergraduate MBBS curriculum in our country is still in the traditional mode. Generally it is teacher centred, discipline based, information gathering and hospital based with no options or elective modules. The main part of the curriculum consists of lectures, tutorials, practicals and ward teaching classes with a limited number of 
problem based sessions. The learning task is to reproduce the subject matter in the final examination.

During admission in medical education attempt was made to ensure that all the students' getting admitted in MBBS course are of similar qualities. As all the students' of MBBS course are of same capabilities but many of them failed during the course of studying. When students' failed in the examination, they have gone to repeat classes and training for a period of six months before they reappear and various support systems are provided them so that they can pass. As a result they might perceive the educational environment in different way. So it is important to identify what factor of environment may influence them to perceive different from those who succeed. Here we are considering the students who passed 1st professional examination in one attempt as academic achievers and who need more than one attempt to passed that examination as academic under achievers.

Inventories measuring learning environment in medical education are widely being used. ${ }^{9}$ In the present study DREEM (Dundee Ready Education Environment Measure) was used. It is a reliable and validated instrument that identifies specific problem areas within an institution for different components of educational environment and also identify strength and weakness of environment. ${ }^{9,10}$ As DREEM is a unique inventory to measure educational environment so, the present study was intended to find out whether there is any difference in perceptions of educational environment of academic achievers and under achievers using this inventory. This study also intend to identify whether there is any gender differences in perception in both academic achievers and underachievers and attempt was also made to identify problem areas in which necessary measures should be taken.

\section{Methods}

Dundee Ready Education Environment Measure (DREEM) questionnaire, is a generic, highly reliable and diagnostic inventory ${ }^{11}, 12,13$ was used to collect data on educational environment. It has been widely used as a tool to gather information about the educational environment in many institutes in many countries. ${ }^{14,15}$ It was originally developed at Dundee and has been validated as a universal diagnostic inventory for assessing the quality of educational environment of different institutes. 9

The DREEM questionnaire was administered to 1610 medical students' of clinical phase (3rd, 4th and 5 th year) of 15 medical colleges. The questionnaire was administered at the end of a scheduled lecture class on different occasions. Before administration the questionnaire the class was addressed regarding the purpose and different aspects of questionnaire for providing appropriate information, stressing the anonymity of the participants and the fact that the data could not be tracked to individual participants. It was also explained that the data would be used for quality assurance as well as for research purpose and their cooperation was requested. After distribution they were allowed 20 minutes to fill up the questionnaire and then the completed questionnaire were returned back in the same class.

The 50 items of DREEM were scored on a fivepoint likert scale with $4=$ Strongly Agree, $3=$ Agree, 2 = Unsure, $1=$ Disagree and $0=$ Strongly Disagree. Nine of the 50 items $(4.8,9,17,25,35$, $39,48,50)$ were negative and scored in reverse. The inventory yields two types of information: mean total score for 50 items or each of its 5 subscales and individual item mean scores for each of the 50 item. The 50 -item DREEM has a maximum score of 200 indicating the ideal educational environment as perceived by the students. 8,16

Items that have a mean score of 3.5 or over are real positive points. Any item with a mean of 2 or less should be examined more closely as they indicate problem areas. Items with a mean between 2 and 3 are aspects of the environment that could be enhanced 16. Score for categorized domains, total score and each item were expressed as mean value. Data were analyzed using the statistical package SPSS (11.5 version) and independent sample t-test were used to determine statistically significant difference $(\mathrm{p}<0.05)$.

\section{Results}

Of the total 1610 respondent academic achievers were 1292 and under achievers were 318. Among the academic achiever 659 were male and 633 were female students. Among the academic underachiever 149 were male and 169 were female. 
Table-1. Mean DREEM domain and total scores in academic achievers and under achievers

\begin{tabular}{lllll} 
Domains & $\begin{array}{l}\text { Maximum } \\
\text { score }\end{array}$ & $\begin{array}{l}\text { Academic } \\
\text { achievers } \\
(\mathrm{n}=1292)\end{array}$ & $\begin{array}{l}\text { Academic under } \\
\text { achievers } \\
(\mathrm{n}=318)\end{array}$ & $\begin{array}{l}\text { P } \\
\text { value }\end{array}$ \\
Student's Perceptions of Learning (SPL) & 48 & 27.67 & 27.32 & .47 \\
Student's Perceptions of Teachers (SPT) & 44 & 24.28 & 23.47 & .06 \\
Student's Academic Self-Perceptions (SASP) & 32 & 19.56 & 18.51 & .001 \\
Student's Perceptions of Atmosphere (SPA) & 48 & 24.33 & 23.20 & .01 \\
Student's Social Self Perceptions (SSSP) & 28 & 14.35 & 14.25 & .69 \\
Total DREEM score & 200 & 110.15 & 106.89 & .03 \\
\hline
\end{tabular}

Table I- Shows mean DREEM domain and total score in academic achievers and under achievers. It was observed that students who are academic achievers scored high in every domain than under achievers. Among those statistically significant

differences were found in student's academic self perception and perception of atmosphere. Total DREEM score was also significantly high in academic achievers $(110 / 200)$ than under achievers $(106 / 200)$.

Table-II. Mean item score in academic achievers and under achievers

Domain Item

SPL

1.I am encourage to participate in classes

7.The teaching is often stimulating

13.The teaching is student centred

16. The teaching helps to develop my competence

20.The teaching is well focused

22.The teaching helps to develop my confidence

24. The teaching time is put to good use

25.The teaching overemphasizes factual learning

38.I am clear about the learning objectives of the course

44.The teaching encourages me to be an active learner

47.Long term learning is emphasized over short term learning 48.The teaching is too teacher centred

SPT

2.The teachers are knowledgeable

6.The teachers are patient with patients

8. The teachers ridicule the students

9.The teachers are authoritarian

18.The teachers have good communication skills with patients 2.20

29.The teachers are good at providing feedback to students $\quad 2.14$

32.The teachers provide constructive criticism here 2.08

37.The teachers give clear examples

4

$\begin{array}{ll}\begin{array}{l}\text { Academic } \\ \text { achiever } \\ (\mathrm{n}=1292)\end{array} & \begin{array}{l}\text { Academic under } \\ \text { achiever } \\ (\mathrm{n}=318)\end{array} \\ 2.86 & 2.86 \\ 3.22 & 3.12 \\ 1.31 & 1.31 \\ 2.92 & 2.84 \\ 2.16 & 2.06 \\ 2.76 & 2.73 \\ 2.30 & 2.20 \\ 1.23 & 1.32 \\ 2.43 & 2.51 \\ 2.74 & 2.66 \\ 2.55 & 2.60 \\ 1.33 & 1.34 \\ 3.11 & 3.02 \\ 2.49 & 2.48 \\ 1.15 & 1.03 \\ 1.78 & 1.54 \\ 2.20 & 2.11 \\ 2.14 & 2.20 \\ 2.08 & 2.17 \\ 2.51 & 2.48 \\ 1.72 & 1.49\end{array}$


40.The teachers are well prepared for their class

$2.59 \quad 2.58$

50.The students irritate the teachers

$2.60 \quad 2.48$

SASP 5.Learning strategies which worked for me before continue to work for me now

10.I am confident about my passing this year

$2.17 \quad 2.16$

$2.61 \quad 2.37$

21.I feel I am being well prepared for my profession

$2.33 \quad 2.28$

26.Last year's work has been a good preparation for this year's work

27.I am able to memorize all I need

$2.84 \quad 2.53$

31.I have learned a lot about empathy in my profession

$1.77 \quad 1.67$

$2.81 \quad 2.67$

41.My problem-solving skills are being well developed here $\quad 2.31 \quad 2.18$

45.Much of what I have to learn seems relevant to a career in medicine

$2.79 \quad 2.70$

SPA 11.The atmosphere is relaxed during the ward teaching $\quad 1.65 \quad 1.62$

12.This college is well time-tabled $\quad 2.61 \quad 2.49$

17.Cheating is a problem in this college $\quad 1.56 \quad 1.51$

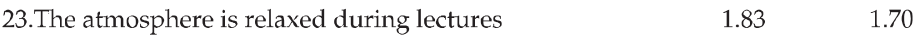

30.There are opportunities for me to develop inter-personal

skills

33.I feel comfortable in class socially

35.I find the experience disappointing $\quad 1.51 \quad 1.36$

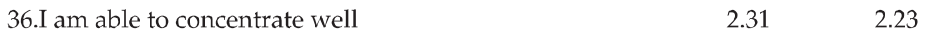

42.The enjoyment outweighs the stress of studying medicine $1.61 \quad 1.54$ )

$\begin{array}{lll}\text { 43.The atmosphere motivates me as a learner } & 2.10 & 2.01\end{array}$

49.I feel able to ask the questions I want $\quad 1.61 \quad 1.55$

SSSP 3.There is a good support system for students who get stressed

$1.13 \quad 1.16$

4.I am too tired to enjoy the course $\quad 1.37 \quad 1.19$

14.I am rarely bored on this course $\quad 1.78 \quad 1.93$

15.I have good friends in this college $\quad 3.20 \quad 2.99$

19.My social life is good $\quad 2.91 \quad 2.93$

28.I seldom feel lonely $\quad 2.26 \quad 2.36$

46. My accommodation is pleasant 1.74$)$

SPL $=$ Student's Perceptions of Learning, SPT = Student's Perceptions of Teachers, SASP $=$ Student's Academic Self-Perceptions, SPA = Student's Perceptions of Atmosphere, SSSP = Student's Social Self Perceptions

Table II- Shows the mean DREEM item score of both academic achievers and under achievers. Total 17 items scored below 2 in both the groups. Among them 3 items from domain 1 i.e. student's perception of learning $(13,25,48), 3$ item from student's perception of teachers, one item from student's academic self perception, 6 items from student's perception of atmosphere and 4 items from student's social self perception. In addition academic under achievers shows one item scored $<2$ was 34 i.e they feel that atmosphere is not relaxed during tutorials / seminars. In both group item 7 and 2 scored $>3$ i.e. sometimes teaching is stimulating and teachers are knowledgeable. In addition academic achievers scored $>3$ in item 15 i.e they have good friends in college. 
Table-III. Items showing significant differences between academic achievers and under achievers

\begin{tabular}{|c|c|c|c|c|}
\hline Domain & Items & $\begin{array}{l}\text { Academic } \\
\text { Academic } \\
(n=1292)\end{array}$ & $\begin{array}{l}\text { achiever } \\
\text { under achiever } \\
(\mathrm{n}=318)\end{array}$ & P value \\
\hline SPL & 7. The teaching is often stimulating & 3.22 & 3.12 & .04 \\
\hline \multirow[t]{4}{*}{ SPT } & 2. The teachers are knowledgeable & 3.11 & 3.02 & .01 \\
\hline & 8. The teachers ridicule the students & 1.15 & 1.03 & .05 \\
\hline & 9. The teachers are authoritarian & 1.78 & 1.54 & .01 \\
\hline & 39. The teachers get angry in class & 1.72 & 1.49 & .004 \\
\hline \multirow[t]{4}{*}{ SASP } & 10. I am confident about my passing this year & 2.61 & 2.37 & .001 \\
\hline & $\begin{array}{l}\text { 26. Last year's work has been a good } \\
\text { preparation for this year's work }\end{array}$ & 2.84 & 2.53 & .001 \\
\hline & $\begin{array}{l}\text { 31. I have learned a lot about empathy in my } \\
\text { profession }\end{array}$ & 2.81 & 2.67 & .03 \\
\hline & $\begin{array}{l}\text { 41. My problem-solving skills are being well } \\
\text { developed here }\end{array}$ & 2.31 & 2.18 & .05 \\
\hline \multirow[t]{2}{*}{ SPA } & $\begin{array}{l}\text { 34. The atmosphere is relaxed during tutorials/ } \\
\text { seminars }\end{array}$ & 2.02 & 1.85 & .03 \\
\hline & 35. I find the experience disappointing & 1.51 & 1.36 & .03 \\
\hline \multirow[t]{3}{*}{ SSSP } & 4. I am too tired to enjoy the course & 1.37 & 1.19 & .01 \\
\hline & 14. I am rarely bored on this course & 1.78 & 1.93 & .05 \\
\hline & 15. I have good friends in this college & 3.20 & 2.99 & .001 \\
\hline
\end{tabular}

SPL $=$ Student's Perceptions of Learning, SPT $=$ Student's Perceptions of Teachers, SASP $=$ Student's Academic Self-Perceptions, SPA= Student's Perceptions of Atmosphere, SSSP= Student's Social Self Perceptions

Table-III Shows significant differences in item between academic achievers and under achievers. Total 14 items shows significant difference. Among them one item from students perceptions of learning, four items from students perceptions of teachers, four items from students academic self perception, two items from students

perceptions of atmosphere and three items from students social self perception. In most items academic achievers scored high than under achievers but in one item under achievers scored high than achievers i.e. they are rarely bored on this course.

Table-IV. Items showing significant differences between male and female academic under achievers

\begin{tabular}{lll} 
Items & $\begin{array}{l}\text { Males } \\
(\mathrm{n}=149)\end{array}$ & $\begin{array}{l}\text { Females } \\
(\mathrm{n}=169)\end{array}$ \\
\hline $\begin{array}{l}\text { 2. The teachers are knowledgeable } \\
\text { 5. Learning strategies which worked for me before continue to }\end{array}$ & 2.88 & 3.14 \\
work for me now & 1.85 & 2.43 \\
6. The teachers are patient with patients & 2.26 & 2.67 \\
18. The teachers have good communication skills with patients & 1.93 & 2.27 \\
24. The teaching time is put to good use & 2.03 & 2.33 \\
29. The teachers are good at providing feedback to students & 1.95 & 1.42 \\
31. I have learned a lot about empathy in my profession & 2.54 & 2.78 \\
32. The teachers provide constructive criticism here & 2.01 & 2.33 \\
Total DREEM score & 104.74 & 108.79 \\
\hline
\end{tabular}


Table- IV Shows the items in which significant difference was observed between male and female academic under achievers. Among them one item (24) from students perceptions of learning, five items from students perceptions of teachers and two items from students academic self perception.
Female students' scored more than male in seven items and in one item (29) male students' scored high than female i.e teachers are good at providing feedback to students. This table also shows that overall DREEM score was high in female $(108 / 200)$ than male $(104 / 200)$ students.

\section{Table-V. Items showing significant differences between male and female academic achievers}

Items

2. The teachers are knowledgeable 2.993 .23

5 . Learning strategies which worked for me before continue to work for me now

6. The teachers are patient with patients

9. The teachers are authoritarian

10. I am confident about my passing this year

12. This college is well time-tabled

15. I have good friends in this college

17. Cheating is a problem in this college

18. The teachers have good communication skills with patients

21. I feel I am being well prepared for my profession

27. I am able to memorize all I need

29. The teachers are good at providing feedback to students

31. I have learned a lot about empathy in my profession

35. I find the experience disappointing

36. I am able to concentrate well

37. The teachers give clear examples

40. The teachers are well prepared for their class

43. The atmosphere motivates me as a learner

45. Much of what I have to learn seems relevant to a career in medicine

46. My accommodation is pleasant

49. I feel able to ask the questions I want

Total DREEM score

\section{Male Female \\ $(n=659) \quad(n=633)$}

$1.97 \quad 2.37$

$2.32 \quad 2.67$

$1.66 \quad 1.90$

$2.76 \quad 2.45$

$2.45 \quad 2.76$

$1.48 \quad 1.66$

$3.27 \quad 3.12$

$2.10 \quad 2.30$

$2.45 \quad 2.19$

$1.85 \quad 1.68$

$2.03 \quad 2.26$

$2.72 \quad 2.90$

$1.62 \quad 1.88$

$2.24 \quad 2.39$

$2.43 \quad 2.59$

$2.42 \quad 2.77$

$2.02 \quad 2.19$

$2.73 \quad 2.84$

$1.44 \quad 1.58$

$2.52 \quad 2.68$

$108.12 \quad 112.27$


Table-V Depicts the items showing significant differences between male and female academic achievers. Overall 21 items shows significant difference between male and female students, among them 8 items from students' perceptions of teachers, 6 items from students academic self perception, 5 items from students perceptions of atmosphere and 2 items from students social self perception. In most cases female students' scored high than male but in four items $(10,17,21,27)$ male students' scored high than female i.e. they feel more confident about passing, cheating is problem, they are well prepared for their profession and they able to memorize all they need. DREEM total score was high in female $(112 / 200)$ students than male $(108 / 200)$ was also shown in this table.

Discussion

Measurement of the educational environment is important and can lead to an enhancement of the students learning experience and achievements. ${ }^{17}$ This cross sectional descriptive study was carried out on a sample (1610) of medical students of MBBS course with a view to determine the perception of academic achievers and under achievers on educational environment using DREEM inventory.

The overall DREEM score given by the academic achievers and under achievers were found to be $110 / 200$ and $106 / 200$ respectively. Taking the above score into consideration students overall perceptions regarding educational environment was found to be positive. Our finding corresponds with Mayya and Roff ${ }^{5}$ where they observed that the overall DREEM score in academic achievers $(108 / 200)$ was high than under achievers $(101 / 200)$. Same observation was made by Pimparyon et $\mathrm{al}^{12}$ where they found nursing students who are academic achievers scored high grade point average (GPA) than non achievers. However in another study Abraham et $\mathrm{al}^{18}$ found academic achievers scored low $(112 / 200)$ than academic under achievers $(119 / 200)$. They also conclude that students' perceptions of their learning environment influences their selection of learning approaches which are correlated with their academic achievement. The rating of academic achievers and under achievers suggests that perceptions about the educational environment are associated with learning outcome. There are studies in the literature suggesting that failing students' perceived their learning context in atypical ways. ${ }^{5,12}$ The students who perceive their learning environment more positively are more likely to develop desirable approaches in learning and more likely to be successful than those who perceive it less positively. Students' perceptions of the learning environment influence their selection of learning approaches, which are correlated with their academic achievement. ${ }^{12}$

Important findings of the present study are the clearly identified differences in perceptions of the same educational environment between academic achievers and under achievers. When compared domain scores it was obserbed that academic achievers scored high in all domains than academic under achievers but significantly high in two domain i.e. students' academic self perception and students' perception of atmosphere. These findings are consistent with others ${ }^{5,12}$ and suggest that low academic achievement is characterized by less satisfaction with the educational environment and perceived support system may not be adequate. However in an Indian medical school Abraham et a $1^{18}$ found that academic under achievers scored high than academic achievers in most of the domain and significantly high in perceptions of learning and teachers and they conclude that academic support system were perceived in the right manner by the academic under achievers.

Item wise comparison between two groups found that many aspects of the educational environment need to be enhanced. In both group items scored less than 2 are mostly from students' perception of atmosphere and social self perception. Items of these two domains need immediate attention to improve. Item wise comparison shows that in most of the items academic achievers scored high than under achievers. Academic under achievers have significant lower score than academic achievers in items of students' perception of teachers, academic self perceptions and social self perception. Same observations were made by Mayya and Roff. Academic achievers are more satisfied and likely to be develop desirable approaches for learning and more likely to be successful than those who perceive it less positively as explained by Pimparyon et al. ${ }^{12}$ So it is necessary to take step to improve those areas so that both groups can perceive the environment as same with special attention to those areas where score is very low such as perception of teachers, academic self 
perception and social self perceptions.

Gender wise comparison of total DREEM score shows female $(108 / 200)$ in the academic under achievers perceived high than male $(104 / 200)$ in most of the items and total score. Female students' of academic under achievers have significant high score than male in items of their perception of teachers and academic self perceptions. Female students feel more positive than male regarding teachers are knowledgeable, have patient with patients, have good communication skills with patients and are good to provide feedback and give constructive criticism to them. Female students also feel that teaching time is put to good use, they learn empathy about their profession. Same observation was made by Abraham et al ${ }^{18}$ but different observation was made by Mayya and Roff ${ }^{5}$ where male scored more positive than female students.

In academic achievers when comparing total score female $(112 / 200)$ students' perceive more positive than male $(108 / 200)$ and significantly high score was found regarding their perceptions of teachers and of atmosphere. Item wise comparison shows that female students' feel more positive than male that teachers are knowledgeable, patient with patients, have good communication skills with patients, provide feedback and give clear example, college is well time tabled, atmosphere motivate them as learner, accommodation is pleasant, feel free to ask question but also disappointing experience. On the other hand male feel more positive than female in items i.e.- they are confident about passing, college cheat with them, they feel they are well prepared for their profession and they can memorize all they need. Similar observations was made by Abraham et $\mathrm{al}^{18}$ but in another study Mayya and Roff ${ }^{5}$ observed male scored high than female students in most of the items. In both the groups female students' scored high may be due to they perceive more positive than male in perceptions of teachers, atmosphere and social self perception of educational environment.

\section{Conclusion}

Continuous quality improvement and innovation are very essential in a medical college. Perception of academic achievers was found significantly different from those of academic under achievers in the same institution. More importance should be given to the perceptions of students' to improve the educational environment as perceptions are associated positively with learning outcome, learning approach and attitude to studying ${ }^{12}$. Positive attitude and deep approach are linked with academic progress or success and later on reflected by positive perception regarding educational environment. The present study also revealed problematic areas in the medical college environment wherein remedial measures should be taken to those areas specially in the subscales of academic self perception and perception of atmosphere. Information obtained from this study will give important feedback to curriculum planners and change managers of the faculty for necessary improvement.

\section{References}

1. Bassaw B, Roff S, Mc Aleer S, Roopnarinesingh S, DeLisle J, Teelucksingh S, Gopaul S. Students'perspectives on the educational environment, Faculty of medical sciences, Trinidad. Medical Teacher. 2003; 25: 522-526.

2. Genn JM. AMEE Medical Education Guide No23 (Part 1): Curriculum, environment, climate, quality and change in medical education- a unifying perspective. Medical Teacher. 2001; 23: 337- 44 .

3. Kendall MC, Hesketh EA, Macpherson SG. The learning environment for junior doctor training what hinders what helps. Medical Teacher; 2005; 27: 619-23.

4. Al-Hazimi A, Zaini R, Al-Hyiani A M, Hassan N, Gunaid A, Ponnamperuma G, Karunathilake I, Roff S, McAleer S, Davis M Educational Environment in Traditional and Innovative Medical Schools: A Study in Four Undergraduate Medical School. Education for Health. 2004;17:192-203.

5. Mayya S. Roff S. Students' Perceptions of Educational Environment : A Comparison of Academic Achievers and Under-Achievers at Kasturba Medical College, India. Education for Health. 2004; 17: 280-291.

6. Glinskiene R, Lipinskiene D. The factors of educational environment: Their influence on students approach to learning. 2004. http://www.ceeol.com/aspx/getdocument.aspx?

7. Demiroren M, Palaoglu O, Kemahli S, Ozyurda F, Ayhan HI. Perceptions of Students in Different Phases of Medical Education of Educational Environment: Ankara University Faculty of Medicine. 2008. http.//www.med-ed-online.org 
8. Till H. Climate Studies: Can students' perceptions of the ideal educational environment be of use for institutional planning and resource utilization. Medical Teacher. 2005; 27: 332-37.

9. Roff S, McAleer S, Harden RM, Al-Qahtani M, Ahmed AU, Deza H, Groenen G, Primparyon P Development and validation of the Dundee Ready Education Environment Measure (DREEM). Medical Teacher. 1997; 19: 295-98

10. Jiffry MTM, McAleer S, Fernando S, Marasinghe RB. Using the DREEM questionnaire to gather baseline informationon an evolving medical school in Sri Lanka. Medical Teacher. 2005; 27: 348-52.

11. Filho GO, Vieira JE, Schonhorst L. Psychometric properties of the Dundee Ready Educational Environment Measure (DREEM) applied to medical residents. Medical Teacher. 2005; 27: 343-47.

12. Pimparyan P, Roff S, Mc Aleer S, Poonchai B, Pemba S. Educational environment, Students approaches to learning and academic achievement in a Thai nursing school. Medical Teacher. 2000; 22: 359-64.

13. Varma R, Tiyagi E, Gupta JK. Determining the quality of educational climate across multiple undergraduate teaching sites using the DREEM inventory. BMC Medical Education. 2005; 5(1); 8 . BioMed Central Full Text

14. Roff S, McAleer S, Ifere OS \& Bhattacharya S. A global diagnostic tool for measuring educational environment comparing Nigeria and Nepal. Medical Teacher. 2001; 23(4): 377-81.

15. Roff S. The Dundee Ready Educational Environment Measure (DREEM)-a generic instrument for measuring students' perceptions of undergraduate health professionals curricula. Medical Teacher. 2005; 27: 322-25.

16. McAleer S, Roff S. A practical guide to using the Dundee Ready Education Environment Measure (DREEM) 2003.

http://web.onetel.net.uk/mikeharris/waco/dreems2.doc

17. Zaini $R$ The use of DREEM as curriculum need analysis tool. Medical Teacher. 2005; 27: 385.

18. Abraham RR, Ramnarayan K, Pallath V, Torke S, Madhavan M, Roff S. Perceptions of academic achievers and under achievers regarding learning environment of Melaka Manipal Medical College (Manipal campus), Manipal India, using DREEM the Inventory. South East Asian Journal of Medical Education, Inaugural issue. 2008; 18-24. 